\title{
Poetic Journeys and Other Metaphors Underlying Literary Criticism of Poetry in English and Russian
}

\section{Viagens poéticas e outras metáforas subjacentes à crítica literária de poesia em inglês e russo}

\author{
Inesa Šeškauskienë* \\ Vilnius University \\ Vilnius / Lithuania \\ Oksana Valentjeva** \\ Vilnius University \\ Vilnius / Lithuania
}

\begin{abstract}
The paper sets out to examine the metaphoricity of the discourse of literary criticism dealing with poetry. The research carried out in the framework of contemporary metaphor studies relying, first of all, on the Conceptual Metaphor Theory and its followers, attempts to uncover metaphors structuring the discourse of literary criticism in two distinct cultures - English and Russian. The methodology of the investigation is based on the key principles of the metaphor identification procedure (STEEN et al., 2010) and metaphorical patterns (STEFANOWITSCH, 2006). The results suggest that the main source domain for conceptualizing poetry in literary criticism in both languages is A PERSON. However, this domain features much more prominently in English, whereas the domains of SOUND AND MUSIC, PAINTING and JOURNEY are more relevant in Russian. Many metaphors are inevitably evaluative - employed to express the writer's positive or negative attitude.
\end{abstract}

KEYWORDS: literary criticism; poetry; metaphor; source domain; English; Russian.

RESUMO: Este estudo se propõe a investigar a metaforicidade do discurso da crítica literária relacionada à poesia. A pesquisa desenvolvida no quadro dos estudos contemporâneos da metáfora se apoia, em primeiro lugar, na

\footnotetext{
*inesa.seskauskiene@flf.vu.lt

**ksenija.val@gmail.com
} 
Teoria da Metáfora Conceitual e seus seguidores, e busca revelar metáforas que estruturam o discurso da crítica literária em duas culturas distintas - a inglesa e a russa. A metodologia de pesquisa se baseia nos pressupostos do Método de Identificação da Metáfora (STEEN et al., 2010) e padrões de metáforas (STEFANOWITSCH, 2006). Os resultados sugerem que o principal domíniofonte para conceitualizar poesia na crítica literária nos dois idiomas é PESSOA. Contudo, esse domínio se destaca muito mais em inglês, enquanto que os domínios SOM, MÚSICA, PINTURA e VIAGEM se sobressaem mais em russo. Inevitavelmente, muitas metáforas são de cunho avaliativo - empregadas para expressar as atitudes positivas ou negativas do escritor.

PALAVRAS-CHAVE: crítica literária; poesia; metáfora; domínio-fonte; inglês; russo.

\section{Introduction}

Literary criticism is concerned with commenting and evaluating literary works and is not necessarily focused on criticising, or indicating the faults in a disapproving way (see also the definition of criticism in Soanes \& Stevenson, 2005). The discourse of literary criticism is rather specific due to its academic status, on the one hand, and due to its object of study, which is a literary text, on the other. The metaphoricity of fiction, often treated as a creative activity, the arts, has never been questioned - either by the adherents of the classical view of metaphor or scholars taking other different approaches, including those working within the Conceptual Metaphor Theory (CMT).

In the classical, Aristotelian framework, metaphors are considered an inalienable feature of literary texts, where they serve as decoration, and are a signal of individual, original creativity. Metaphors in those texts are confined to linguistic expression, and are thought of as exceptional, unique and hardly ever produced in everyday speech (LAKOFF \& JOHNSON, 2003; DEIGNAN, 2005). Therefore, it is understandable that many literary works have been mostly valued by critics for their uniqueness and originality (SEMINO \& STEEN, 2008).

The CMT and further research have modified the traditional, "decorative" understanding of metaphor, expanding it into everyday language and moving it into the realms of reasoning and thought, including its multifarious modes of manifestation, such as everyday conversation, as well as academic, political, news and a wide range of other discourses, including literature (LAKOFF \& JOHNSON, 2003). The CMT and further metaphor researchers have not questioned the creative nature of literary texts. Rather, they admit that, in literature, not only are novel 
metaphors created, but conventional conceptual metaphors are also exploited in novel ways (SEMINO, 2008). In other words, literature more frequently gives impetus to uncovering new aspects of conventional entrenched metaphors rather than entirely new conceptual metaphors. The latter are not excluded; however, they are often confined to unusual, individually created, often unique expressions (see the continuum of metaphor classification as presented in Deignan, 2005, p. 39-47). Due to a creative and innovative nature of fictional discourse, metaphors in fiction are usually much more easily identifiable than in other discourses (STEEN, 2004).

The function of literary criticism is to respond to the creativity of the text, as well as to interpret and evaluate it. Like any other professional discourse, literary criticism operates within a specific established framework under the umbrella of an academic discourse. However, as noted in a recent study by Hermann (2013, p. 125-126): "there is not one 'academic discourse', but a number of specialised subfields with different metaphorical word usages." Following the view that each field-specific academic discourse is framed by a discourse-specific metaphorical projection (ZINKEN et al., 2008 apud SEMINO, 2011), we assume that literary criticism of poetry gives preference to its own metaphors. This claim runs in line with the ideas of other researchers (KÖVESCES, 2010; LAKOFF \& JOHNSON, 1987; JOHNSON \& LARSON, 2003; JOHNSON, 2007; NÚNEZZ 2008; SEMINO, 2011), who have on many occasions highlighted that fields such as mathematics, philosophy, music, politics or emotions are in fact structured by their metaphors.

The present research aims to uncover metaphors, structuring the discourse of literary criticism dealing with poetry in two rather distinct cultures - English and Russian. As literary criticism is evaluative by default, we will also try to identify the role of metaphor in rendering the author's evaluative approach.

\section{CMT and embodiment}

The framework of the present research is based on CMT, which is closely linked to the principle of embodiment. The key idea of CMT is concerned with the pervasiveness of metaphor in human thought and understanding, in which one domain of human experience, usually more abstract, is understood in terms of another domain, usually more concrete. Hence, life can be understood as a journey or argument in terms of war. The theory introduced by Lakoff and Johnson (2003) expanded the understanding of metaphor from a solely textual and linguistic to a 
cognitive level, which also includes language as one of manifestations of human cognition. Thus, life understood in terms of a journey is manifested in numerous metaphorical expressions (also called linguistic metaphors ${ }^{1}$ ) such as crossroads, bumpy road, etc. used in reference to one's life 2 . The two domains are usually referred to as source (more concrete) and target (more abstract) domains. In the above example, LIFE is a target domain, while JOURNEY is a source domain. Metaphors are written as A (target domain) is $\mathrm{B}$ (source domain); in the above case, LIFE IS A JOURNEY.

The emergence and further development of CMT, eventually supported by ample empirical evidence, has been, to a great extent, shaped by embodiment. Metaphor is primarily a matter of thought, and our metaphorical reasoning is grounded in bodily experience. As noted by Gibbs et al. (2004, p. 1190): "the poetic value and the communicative expressiveness of metaphoric language partly arise from its roots in people's ordinary, felt sensations of their bodies in action." Abstract elements are more difficult to comprehend than concrete elements; consequently, people tend to interpret these in terms of more 'down to earth' phenomena that can be touched, seen, raised, pushed, as well as have shape, weight, colour, etc., like many concrete objects around us. As seen in the above example of life understood as a journey, life is much more abstract than journey, in which travellers have direct access to their bodily experience, which helps them formulate their own reasoning about life. Thus, people see crossroads and bumpy roads, which are usually hindrances on their otherwise smooth driving. Therefore, they transfer their travelling experiences to the understanding of difficult situations in life, when one must take decisions. The physical world around us, including the bodies of our own and others, is a rich source domain of metaphors. Reasoning and writing about literary criticism in this respect is no exception.

\section{Methodological issues}

The corpus of the present study consists of English and Russian articles of literary criticism, focusing on concrete poetic works, including approximately 100,713 words. The English texts were collected from the following journals: The English Review, Wordsworth Circle, New England

\footnotetext{
${ }^{1}$ Throughout the paper, the terms metaphorical expression and linguistic metaphor are treated as synonyms and used interchangeably.

${ }^{2}$ For numerous examples and their interpretation see also Kövesces (2002, 2010).
} 
Review, The Explicator, Poetry Criticism, Poetry for Students, The American Poetry Review, The Worcester Review, Victorian Poetry, Northwest Review, ANQ, Contemporary Literary Criticism, Modern Age, and Studies in the Literary Imagination. The articles were accessed through the Literary Resource Centre's online database. The overall scope of the English data includes 27 articles, which include 50,031 words. The Russian data was collected from the following journals: Новое литературное обозрение ['New Literary Review'], Новый мир ['The New World'], Наи современник ['Our Contemporary'], Октябрь ['October'], Вопросы литературы ['The Questions of Literature'], Филология в системе современного университетского образования ['Philology in the System of Contemporary University Education'] and Народная культура сегодня и проблемье ее изучения ['National Culture Today and the Problems of Its Study']. Some of these articles were accessed via the Internet, whereas some were only available in hard copy. The total number of the articles in Russian is 26 , totalling 50,682 words. The publication period of the articles is ten years: from 2003 to 2012. All selected articles are listed at the end of this paper.

The analysis of the data consisted of two stages: the identification of linguistic metaphors focusing on poetry and their interpretation. In the identification stage, two methodologies were applied: the metaphor identification procedure (MIP) and metaphorical patterns. The main principles of the MIP were suggested by the Pragglejaz Group (2007) and further elaborated by Steen and colleagues (STEEN et al., 2010, 2010a). The four key steps of the MIP are presented below:

1) Read the entire text-discourse to establish a general understanding of the meaning.

2) Determine the lexical units in the text-discourse.

3) (a) For each lexical unit in the text, establish its meaning in context, that is, how it applies to an entity, relation or attribute in the situation evoked by the text (contextual meaning), taking into account what comes before and after the lexical unit.

(b) For each lexical unit, determine if it has a more basic contemporary meaning in other contexts than that presented in the given context. For our purposes, basic meanings tend to be: 
- More concrete [what they evoke is easier to imagine, see, hear, feel, smell and taste];

- Related to bodily action;

- More precise (as opposed to vague);

- Historically older.

Basic meanings are not necessarily the most frequent meanings of the lexical unit.

(c) If the lexical unit has a more basic current-contemporary meaning in other contexts than the given context, decide whether the contextual meaning contrasts with the basic meaning but can be understood in comparison with it.

4) If yes, mark the lexical unit as metaphorical (PRAGGLEJAZ GROUP, 2007, p. 3).

Second, to pursue the aim of the paper, the principles of the above procedure were applied to contexts with the poetry-related key words, such as poem, poetry, stanza, lines, etc. It is also important to mention that metaphors emerge on the basis of contextual contrast, which Stefanowitsch (2004, 2006) described in terms of metaphorical patterns. A metaphorical pattern is "a multi-word expression from a given source domain (SD) into which one or more specific lexical items from a given target domain (TD) have been inserted" (STEFANOWITSCH, 2006, p. 66). In the utterance he shot my arguments, shooting comes from the war domain, whereas arguments are from the domain of discussion. Normally, we do not shoot arguments. At first, sight shooting and arguments are semantically incompatible; consequently, a contrast or semantic clash (term adopted from HEYWOOD, SEMINO \& SHORT, 2002, p. 46-47) is produced. However, due to our ability to transfer between experiential domains, we are able to process and understand the meaning of the utterance.

Later in this paper, the interpretation of the results will be discussed, largely based on CMT, which will help to uncover the link between two conceptual domains - the source and the target, where the latter is seen in terms of the former (see also Lakoff \& Johnson, 2003; Kövecses, 2010). 
Multiple correspondences between the source and the target are commonly referred to as mappings. Further studies on metaphor have also been taken into consideration (DEIGNAN, 2005; SEMINO, 2006, 2008).

\section{Results and discussion. Overall tendencies of metaphoricity}

As demonstrated in Table 1 below, literary criticism in English and Russian employs a similar number of metaphorical expressions when reasoning about poetry. In quantitative terms, Russian seems to be slightly more metaphorical than English. Taking into account that the overall data corpus includes approximately 100,000 words, the difference between the two sub-corpora in terms of metaphoricity becomes insignificant.

Table 1: Frequency of metaphorical expressions (MEs) in English (EN) and Russian (RU)

\begin{tabular}{l|l|l|} 
& EN & RU \\
\hline Tokens of MEs & $574(43.5 \%)$ & $744(56.5 \%)$ \\
\hline Types of MEs & $527(46.2 \%)$ & $614(53.8 \%)$ \\
\hline Number of tokens of MEs per 10,000 words & 115 & 147 \\
\hline Number of types of MEs per 10,000 words & 105 & 121
\end{tabular}

In Table 2 below, the source domains of the conceptual metaphors identified in the data are enumerated in the order of the overall number of MEs (types and tokens in corpus linguistic terms). Both cultures, English and Russian, give preference to conceptualizing poetry as a human being or, more generally, as a living organism. They make up more than half of all MEs in English and slightly less than 20 percent of MEs in Russian. However, English seems to do so three times more frequently than Russian. In Russian, the source domains of a PERSON (LIVING ORGANISM), SOUND AND MUSIC, PAINTING, CONTAINER and JOURNEY are equally important each resulting in about $100 \mathrm{MEs}$ in the corpus. The source domains of SOUND AND MUSIC, PAINTING, JOURNEY and BUILDING in Russian are two to three times more productive than in English. In Russian, the source domain of 
SOUND AND MUSIC is even more productive than PERSON (LIVING ORGANISM). CONTAINER metaphors are more or less equally frequent in both cultures. The source domains of PLANTS, SEWING, FILMING, FOOD and DISEASE feature much less prominently in either culture.

Table 2: Source domains of poetry metaphors in English (EN) and Russian (RU)

\begin{tabular}{|c|c|c|c|c|}
\hline \multirow{2}{*}{\multicolumn{2}{|c|}{$\begin{array}{l}\text { Source domain } \\
\text { EN }\end{array}$}} & \multicolumn{3}{|c|}{ Types/tokens of MEs } \\
\hline & & \multirow{2}{*}{$\frac{\text { RU }}{315 / 333^{4}}$} & \multicolumn{2}{|l|}{ Total } \\
\hline 1. & PERSON (LIVING ORGANISM) ${ }^{3}$ & & $104 / 116$ & $419 / 449$ \\
\hline 2. & SOUND AND MUSIC & $31 / 40$ & $112 / 142$ & $143 / 182$ \\
\hline 3 & PAINTING & $33 / 36$ & $99 / 143$ & $132 / 179$ \\
\hline 4. & CONTAINER & $67 / 80$ & $85 / 97$ & $152 / 177$ \\
\hline 5. & JOURNEY & $57 / 58$ & $99 / 106$ & $156 / 164$ \\
\hline 6. & BUILDING & $12 / 12$ & $47 / 58$ & $59 / 70$ \\
\hline 7. & PLANTS AND BIOLOGICAL PROCESS & $3 / 4$ & $34 / 39$ & $37 / 43$ \\
\hline 8. & WEAVING AND SEWING & $6 / 8$ & $13 / 17$ & $19 / 25$ \\
\hline 8. & FILMING & $2 / 2$ & $8 / 11$ & $10 / 13$ \\
\hline 10. & FOOD & $1 / 1$ & $6 / 7$ & $7 / 8$ \\
\hline \multirow[t]{2}{*}{11.} & DISEASE & -- & $7 / 8$ & $7 / 8$ \\
\hline & Total & $527 / 574$ & $614 / 744$ & \\
\hline
\end{tabular}

${ }^{3}$ The source domain of A PERSON is treated together with that of A LIVING ORGANISM, since the latter subsumes the former and they are not always easy to be distinguished. In some cases, only the more general domain of a LIVING ORGANISM is identifiable. For more details, see section 4.1.

${ }^{4}$ Throughout the paper, the figures are used to indicate the number of types of MEs before the slash and the number of tokens after it. 
The following section will discuss each source domain in more detail, beginning with PERSON (LIVING ORGANISM) as the most prolific source domain in English. Next, the study will move on to analyse SOUND AND MUSIC and PAINTING metaphors, which seem to be quite important in the Russian data, though much less prominent in English. Afterwards, the study will discuss JOURNEY metaphors, which demonstrate significant differences in terms of frequency in the two cultures. The CONTAINER source domain, which features equally frequently in English and Russian, and other, less prominent, metaphors will be dealt with towards the end of the paper.

\subsection{The source domain of A PERSON (LIVING ORGANISM)}

In ample research into metaphors, the ubiquity of personification is hardly ever questioned. In academic discourse in general, where researchers refer to other authors, there is a tendency to refer to such authors' papers as persons, especially in English (ŠEŠKAUSKIENĖ, 2010, 2013). Hence, we frequently encounter such phrases as the paper suggests, claims, gives more details, etc. Arguably, such expressions could be also interpreted within the metonymy A PRODUCT FOR ITS PRODUCER where the mapping appears between an artefact as a result of human thought (target domain) and a person who created it (source domain) (LOW, 1999). Literary critics discussing poetry often refer to authors of poems by the poems themselves. As a result, a number of metaphorical patterns, where such verbs as say, speak, tell, imply, interpret, mention, read, describe, and explain appear in combination with poem, poetry, stanza, words, lines, couplets, etc. in both English and Russian, and are interpretable within the metaphor A POEM IS AN AUTHOR ${ }^{5}$, for example:

(1) This stanza mentions their awareness of what is happening to them (EN16). ${ }^{6}$

\footnotetext{
${ }^{5}$ As rightly pointed by an anonymous reviewer of this paper, such cases could also be treated within the metaphor-metonymy continuum (on the overlap, see also Deignan, 2005, p. 59-71).

${ }^{6}$ Throughout the text, the sources of all examples are given in round brackets, where EN stands for 'English' and RU - for 'Russian'. The figure that follows is the number of the article in the list of the sources, which is given after the list of references of the paper. In each example, the words and expressions making up a metaphorical pattern are underlined. All Russian examples are translated into English in square brackets. The translations are our own.
} 
(2) This poem speaks with Robert Frost's customary dry, factual, slightly bemused voice (EN16).

(3) Люди нуждались в таких стихотворениях, которые были бы занимательны и [...] правдиво рассказывали о трудовых буднях ['People needed such poems, which would be alluring and truly tell us about everyday life'] (RU26).

English seems to adhere to such patterns much more frequently, which might be concerned with its analytical character. Such patterns as the paper claims, suggests, argues, etc. are deeply rooted in English culture. Inflecting languages, such as Russian or Lithuanian, in such constructions, give preference to the passive voice, especially in reference to the author's works in general (ك̌EŠKAUSKIENĖ, 2010). In Lithuanian, this seems to be linked to a strong movement of language purists, who try to resist any influence of English and, when editing research papers written in Lithuanian, modify the paper claims type of structures into it is claimed in the paper.

Several English MEs refer to poems and poetry as possessing a body; the verbal expression of the poem is conceptualized as skin, for example:

(4) [...] the plaintive body of the poem [...] eloquently states the case of mortality and loss (EN5).

(5) Of these facts, we might infer, there can be no doubt; they are the "objective" layer of the poem, its outer skin (EN11).

In Russian conceptualizing poetry in terms of 'body' has not been identified; however, its physical existence has been signalled by reference to a (human) life-cycle. In the data, we can come across such expressions as be born, live and die, for example:

(6) [...] вокруг нас продолжает жить в лучших своих образиах поэзия 20 века ['Around us the poetry of the $20^{\text {th }}$ century continues to live in its best manifestations'] (RU13)

(7) [...] трудно представить тогдашнее ощущение мёртвенности [...] поэзии ['It is difficult to imagine the feeling of dead poetry of that time'] (RU6). 
In examples (4), (5), (6) and (7), more concrete elements of a living being, such as body or skin, or the more abstract elements of birth, life and death, are not specifically human. Rather, they give a clue to the author's reasoning about poetry in more general terms of a living organism, which also subsumes humans.

The images of life and death in the above examples are loaded with evaluative connotations. Poetry is conceptualized as living is good and praiseworthy. Lifeless or dead poetic works are regarded incompetent.

Our data also demonstrates a tendency to conceptualize poems as humans with character features and capable of experiencing emotions. Thus, in English, couplets are light-hearted, lines are sentimental, the poem confesses, and the lines calm down; whereas in Russian, the lines are talented, sincere, proud, and sincerely willing, the rhythm gets tired, etc. Russian seems to employ emotion-related words more frequently than does English and thus produces a number of rather unexpected, innovative MEs, for example:

(8) В каждом стихотворении отражсается какая-то грань души поэта, какими бы разными по настроению ни были стихи ['In each poem some aspect of a poet's soul is reflected, irrespective of the mood of his/her verse'] (RU17).

(9) Очень гордое письмо, откровенно пренебрегающее наивным читателем [...] ['A very proud, written verse, frankly neglecting the naïve reader'] (RU12).

In a number of MEs in English and Russian, family relations are mapped onto the domain of POETRY. Interestingly enough, with reference to close kinship (nearest cousin, identical twin - example (10) below) between the poetic work in question and another, very famous, piece of poetry expresses the critic's favourable evaluation; he/she praises the author of the poem as the one who is able to write like a Romantic poet. In another case, the critic's reference to rich genealogy is a sign of intertextuality, as the poem in question demonstrates a number of links with previous writers (example (11)). However, a very close relationship between several poetic works is an indication of the poet's inability to move further away from other poets in an attempt to demonstrate his/her originality and creativity (example (12)). In such cases family metaphors are a mark of negative evaluation, for example: 
(10) The ode thus occupies an uncertain place in Abrams's poetics, either the nearest cousin of the greater Romantic lyric or its identical twin (EN17).

(11) Современного исследователя и читателя этого текста Заболоикого увлекает его богатая родословная ['The contemporary investigator and reader is carried away by the rich genealogy of Zabolotsky's text'] (RU24).

(12) Родство [стихов Твардовского] с прозаическими жанрами и послужило поводом к их негативной оченке ['The kinship of Tvardovsky's poems with prose genres has led to their negative evaluation'] (RU26).

In the English data, the notion of divorce appears as an indication of difference, divergence of the poem under study and other poems by the same poet, for example:

(13) This self-reflective intrusion clearly describes the critical distance between itself and its pre-text, intentionally divorcing the poem from the poetry inscribed in its own first lines (EN4).

The source domain of A PERSON (LIVING ORGANISM) in the data under study features very prominently, especially in the English sub-corpus. Poetic works are frequently treated as humans (living organisms). Physical features, such as body or skin, are only employed in English. Character features and emotions are equally important to both English and Russian critics, though Russians seem to employ a larger number of emotion-related words. Family relations are an indication of strength and adherence to tradition; hence, reference to close kinship often marks the high quality of poetry. However, excessively strong adherence to family is interpreted as a lack of creativity and originality, hence a sign of poor quality. In this respect, neither of the two cultures demonstrates significant differences.

\subsection{The source domain of SOUND AND MUSIC}

Sound seems to be synesthetically integrated into a written text. It is quite natural in a written text to refer to other modes of verbal expression 
- listening and speaking. We tend to write about other authors as claiming or saying something rather than writing. In academic papers, due to their interactive nature (HYLAND, 2004; FLØTTUM et al., 2007), writing and speaking naturally blend together.

Poetry and music are also very closely linked: for poetic verse, the rhythm and rhyme, an inalienable feature of many pieces of music, is of utmost importance; also, poetry is often accompanied by music. Presumably, in the human mind, poetry and sound/music eventually merge. Therefore, it is quite logical that SOUND AND MUSIC is one of several domains for metaphorical reasoning about poetry in literary criticism.

As our data suggests, in English, poetry is conceptualized in terms of sound and music much less frequently than in Russian. The number of MEs accounting for sound and music in English is almost three times lower than in Russian (31/40 MEs in English and 112/142 in Russian, see Table 2). English tends to employ rather conventional expressions, such as the sounding of the poem's words, tone of the poem, the poem echoes, music of the verselpoem, etc. Russian seems to be more creative; as a result, alongside such entrenched expressions as звучит слово ['the word sounds'] or тема звучит ['the theme sounds'], Russian literary critics employ such expressions as строка звучашая в другом ритме ['the line sounding in a different meter'], звучит переживание ['anxiety sounds'], звучание определяют стихотворения ['poems determine the sounding'] and обновлённое звучание древнего амфибрахия ['the refreshed sounding of ancient amphibrach']. The words мотив ['motif'] and переклички ['cross-callings/cross-references (between different poetic works)'] have been particularly frequent in the Russian texts, with the former referring to repeatedly occurring ideas in several poems and the latter pointing to associations evoked by one literary work with respect to another, for example:

(14) Состояние «полёта» (сквозной мотив поэзии Афанасьевой) [...] ['A state of 'flying' (a prevailing motif of Afanasyeva's poetry)'] (RU4).

(15) Переклички этого финала с «Пророком» очевидны. ['The crosscallings between this ending and 'The Prophet' are obvious'] (RU21). 
Some expressions evoke very detailed images of people listening to music or playing a particular musical instrument. A talented poet is described as a poet with a fine ear or as a performer capable of sliding the string of tradition or changing the key, for example:

(16) But what clinches, for me, the "Maritime" essence of this poem is Bishop's fine ear for the disembodied voices [...] (EN21).

(17) Кушнер скользит по струне традиции и заставляет её звенеть. ['Kushner slides the string of tradition and makes it ring'] (RU7).

(18) Но, чуткий поэт, он попытался перенастроить тональность и преобразить язык плача в [...] песнь радости. ['But being a sensitive poet he attempted to change the key and convert the speaking of a cry into a song of joy'] (RU24).

The image of a poet mapped onto a performer playing a string instrument seems to persist in Russian. In several cases in the Russian corpus, poetry is referred to as an ever-sounding string (RU7) or poets are touching the same strings to achieve a powerful effect (RU20). Ability to play a string instrument is a means to express the author's positive evaluation. In this respect, Russian seems to be more creatively referring to sound and music than English.

\subsection{The source domains of PAINTING, WEAVING AND SEWING and FILMING}

Interestingly enough, the source domains of PAINTING and other visual arts, such as HANDICRAFTS (WEAVING AND SEWING) and FILMING, are fairly productive domains used to conceptualize poetry in Russian. As our data shows, they are much more frequent in Russian than in English. In English, discussing poetry in terms of painting was attested to in a total of 36 cases (33 types), whereas in Russian 143 cases (99 types) were found. The visually accessible source domain of PAINTING is seen as closely linked to WEAVING AND SEWING and FILMING. The latter two are not very numerously represented in the corpus (WEAVING AND SEWING - 6/8 EN, 13/17 RU; FILMING - 2/2 EN, 8/11 RU), and will be discussed together with painting. 
Both cultures see poets as painters producing pictures, drawings, sketches and portraits. Interestingly enough, landscape is the most frequent genre and appears in 5/6 cases in English and 10/24 cases in Russian. In addition, in Russian, the words изобразить, изображать ['depict, portray'] and their numerous derivatives (such as изображение, изобразительность, изображаемый) are the most frequent. Depiction and portrayal are usually employed alongside descriptions; in descriptive texts, they are used synonymously and have become rather conventional ways of expression. However, the source domain of PAINTING generates many original images as well. For example, in Russian, reference to copying from nature (see (19) below; списанныхх с натуры, lit. 'rewritten from nature') is seen as a sign of perfection and used to praise the poet's work:

(19) [...] таинственным покоем бесстрастного созериания веет от некоторых «пейзажных» и словно списанных с натуры стихов Кропивниикого. ['Some 'landscape' poems painted/rewritten/copied from nature by Kropivnickij emanate a secret quietness of passionless concentration'] (RU3).

The source domain of PAINTING is accessible through vision and is thus closely linked to viewpoint and visual arrangement. Hence, the frequency of expressions referring to vision and distance, such as different angles, remote perspective, bird's eye view, foreground and background, for example:

(20) With highly descriptive language, she comes at her topic - sorrow from four different angles, each expressing what sorrow feels like from the remote perspective of things that do not even experience the emotion (EN14).

(21) [...] уютная суженность зрительной перспективы, ограничивающей поле зрения несколькими шагами [...] делает стихотворение замечательно цельным и законченным ['A cozy narrowed visual perspective limiting the field of view by several steps makes the poem wonderfully whole and complete'] (RU23).

What seems to be especially prominent in the Russian literary criticism is concerned with a large number of MEs referring to colours. Such expressions as богатство красочного состава ['the richness of paints'], насыщенность цвета ['colour saturation'], сияние красок ['shining 
colours'], красочные стихи ['colourful poems'], словесная палитра ['verbal palette'] and иветовая гамма ['palette'], contribute to the 'visualization' of poetry as a picture. Russian, in this respect, offers a much more salient image of poetry.

Another, much less frequently employed, visual source domain is concerned with WEAVING AND SEWING. In English, weaving (of the theme/s) and pattern (used in reference to rhythm) seem to be the only clues to it. In Russian, the focus is on cloth, canvas, thread/s and lining. Thus, we come across such expressions as ткань поэзии ['the cloth of poetry'], стиховая ткань ['poetic cloth'], ткань текста ['the cloth of the text'], сюжетная канва стихотворения ['the canvas of the poem's plot'] and в канву вилетаются ['the canvas is interwoven with']. It is interesting to note that, in reference to the rhythm of a poem, the Russian authors employ a drawing (рисунок) rather than pattern, usually appearing in English. Only in Russian has lining been used to highlight the hidden, yet very important idea of the poem (смысловая подкладка ['semantic lining']). Presumably, threads, especially red thread/s (нити образов ['threads of images'] and красной нитью прошившие ['having sewn with the red thread']), in Russian, are concerned with giving prominence and highlighting. The idiom of a red thread is firmly established in Russian folklore, and is used in discussing political or historical issues in public discourse.

If the source domain of PAINTING in discussing poetry is mostly employed in its static form, the domain of SEWING AND WEAVING evokes a more dynamic image. FILMING, another source domain accessible through vision, is even more dynamic. Not particularly frequent in our data $(6 / 8$ EN and 13/17 RU), FILMING is signalled by such expressions as moving camera, projection and focus, mostly used in reference to a concrete poem, for example:

(22) The "camera" roves, pans, lingers, moves in for an extreme close-up, fixes a moment on the pulsing of the gills [...] (EN11).

(23) Вопрос в ракурсе зрения и скорости монтажа. ['A question of the angle of view and the speed of editing'] (RU13).

The source domain of FILMING is instrumental in highlighting the most important praiseworthy features of poetry, when more dynamic aspects of poetry are highlighted and seen as more vividly contributing to expressing the 
main idea of the poem. FILMING, together with WEAVING AND SEWING, as well as a more static domain of PAINTING, as the most visual domains, help render the discourse about poetry highlighting such features as vividness and expressiveness.

\subsection{The source domain of A JOURNEY}

The JOURNEY domain is one of those domains which have been frequently investigated by metaphor researchers. Notably, it is a frequent source domain to conceptualize life, love, relationship, as well as events in politics, etc. (LAKOFF \& JOHNSON, 2003; KÖVECSES, 2010; SEMINO, 2008; CIBULSKIENE, 2013). As claimed by Lakoff and Johnson (2003), the main input of the JOURNEY source domain is that it defines the target as having a beginning, keeping in constant movement and making gradual progress towards a particular goal - the characteristics that emphasize continuous development and change.

The present study has revealed that the JOURNEY conceptual domain is evoked when discussing the content of the poem, also found in such processes as writing and interpreting poems as well as the poet's career. From the quantitative point of view, Russian tends to employ JOURNEY metaphors more frequently than English (as can be seen in 57/58 EN and 99/106 RU).

Elements of JOURNEY used in reference to the rhythm, tempo, course of events or emotional impact of a poem usually include words indicating direction, means of transport, roads, paths, steps, speed, etc. Interestingly enough, English makes use of such elements as train, speeding, slowing down, (re)turning, taking a direction, moving, and departing. Russian, however, alongside words and expressions with a more general meaning of motion, such as следовать ['follow'] and вернутьсяк началу ['return to the beginning'], amply employs words and expressions that exclusively refer to walking: идти ['go'], доходить ['reach on foot'], ход ['walking'], переход ['crossing on foot'] and длинными шагами ['in long steps']. For example:

(24) The physical effect of reading 'express/unless' causes the reader to slow down abruptly in what was before a run-away train kind of rhythm (EN25).

(25) Предельно сжатое [...] письмо с очень длинными шагами от слова к слову, от ассоииаичи - к следующей. ['highly compressed writing with long steps from word to word, from one association to 
the following'] (RU12).

Not only the content of the poem, but also its interpretation and writing are conceptualized in terms of a journey. In this respect, some culture-specific differences can be observed. English seems to focus on difficulties in interpretation, which is why such journey elements as slowing down or slowing our movement forward, driving the readers away are used. Russian employs such elements of a journey as на пути ['on the way'], направления ['directions'] and ориентирует ['[it] guides'], as well as близко nодойти ['to come close to the essence or meaning of the text']. Therefore, to be able to understand the meaning of a poetic text, English critics tend to slow down and think, whereas Russian critics are more likely to come closer to the object of study, for example:

(26) Задача натего нынешнего исследования - приблизиться к пониманию текста [...] ['The task of the present investigation is to come close to the understanding of the text'] (RU22).

A poet, who is engaged in writing a poem, is sometimes conceptualized as a traveller. The most important thing in both cultures seems to be a forward movement and progress signalled by such elements as moving, steps and pace in English and идти ['walk'], путь ['way'] and в другую сторону ['in another direction'] in Russian. The emphasis is placed on the dynamism of the process of poetry writing.

Elements of journey are employed when discussing the poet's creative career in search of recognition. Both cultures emphasize the poets' search for the right path, sometimes being on the outskirts but searching for alternative or new ways, roads and paths, getting off the road, etc. For example:

(27) In such poems as "The Eolian Harp" and "The Nightingale", however, Coleridge pursues less stormy paths (EN17).

(28) [...] E. Кропивницкий незаметно, «на окраине» основных художественных течений века, прокладывает свой альтернативный nyть в искусстве ['E. Kropivnickij, unnoticed, 'on the outskirts' of the main literary trends of the century; paves his alternative path in art'] (RU3).

Expression in Russian seems to be more diverse than English. 
The Russian corpus includes such cases as искавшая вход ['searching for entrance'], в поисках ['in search of'], приближается к идеологии ['approaches the ideology'], делают поворот ['make a turn'], уходил прочь в одном из возможных направлений ['used to leave in one of the possible directions'], вступившего на тропу ['having taken a path'], искавший новых nутей ['searching for new ways'], сбивался с пути ['got off the road, went astray'] and взяв курс на ['having headed for']. They all help present the poet's professional development through a constant search of new creative possibilities and striving for originality.

It is interesting to note that the element of height, verbalized as a mountain peak, appears in both cultures. Reaching it after a long and tiresome mountain journey suggests that, in their creative life, poets see recognition as their ultimate goal, like reaching the peak, for example:

(29) He [Keats] wishes to be reborn, like the Phoenix, "to fly at my desire", reaching more lofty heights in his art (EN24).

(30) Оно [стихотворение], [...] не представляется мне сколь-либо вериинным из множества его произведений [...] ['It [the poem] does not seem to me peak-like among his multiple works '] (RU9).

In the above examples, climbing a mountain corresponds to gaining success, whereas reaching the peak refers to producing poems that bring fame. These cases indicate the JOURNEY metaphor merging with what Lakoff and Johnson (2003, p. 16) call the HIGH STATUS IS UP metaphor. According to the scholars, status is associated with social power which, in turn, is usually understood in terms of an upward movement. Since a mountain journey presupposes ascension (upward movement), it is logical to suggest that a POETIC CAREER IS A MOUNTAIN JOURNEY may be a specific case of the more general HIGH STATUS IS UP metaphor.

It follows from the discussion above that JOURNEY is a rich source domain for conceptualizing literary criticism dealing with poetry. Journey is employed in reasoning on the content of poems, the process of writing and interpreting them, as well as the poets' creative careers. Russian more frequently employs journey metaphors, which might be why it chooses more diverse ways of expression, whereas English sticks to well-established 
collocations. Moreover, Russian, in many cases, gives preference to moving on foot.

\subsection{The source domains of CONTAINER, BUILDING, PLANTS, FOOD and DISEASE}

As admitted by other authors (see also Lakoff, 1987, Kövecses, 2010), CONTAINER and BUILDING metaphors are among the most frequent metaphors structuring abstract thought. As claimed by Lakoff and Johnson (2003), the concept of containment is universal, as it takes its roots in human bodily experience. Individuals perceive themselves as containers with boundaries and an in-out orientation, and project this understanding into other objects, viewing them as consisting of an inside and an outside.

In our data, the CONTAINER metaphor has been identified in a similar number of MEs in both discourses (67/80 EN and 85/96 RU). Prototypically, poetry and poems are conceptualized as bounded entities filled with certain content. The most frequent indicator of such conceptualization is the preposition in in English and a corresponding preposition $\theta$ (to be pronounced as [v]) in Russian. Thus poems, narratives, lines, rhymes and meters can be conceptualized as bounded entities filled with thought, ideas, words, or even simply space. For example:

(31) How much space is there in the poem, and who should fill it? (EN13).

(32) Как видим, в приведённом стихотворении Я.Купаль ярко присутствует мысль просвещения [...] ['As we see, in the discussed poem by J.Kupala, the idea of enlightenment is brightly present'] (RU16).

Other indicators of containers are elements of opening, filling and closing, entering and bursting. Apart from a large number of utterances with the preposition in(to), other elements pointing to containers are not particularly varied in either Russian or English. However, in the Russian data, the image of a container is extended to include a house, which is being broken into. The image creates a rather dubious effect - on the one hand, the unexpected outburst of emotion signals the strong impact of the poem, on the other hand, the element of criminality is preserved, for example: 
(33) В его стихи снова, после первых, ещё отроческих, проб, полновластно врываются просторы земли [...] ['Into his verse, again, after the first, still very tentative trials, the expanses of the earth burst'] (RU15).

In Russian, there are several other phrases having to do with entering a poem as a house or any other entity, such as введение ['bringing into'], войти в ux [стихов] суть ['go into the essence of the poems'], встуnпem ['[it] enters'], вторгалось ['used to break into'] and ввёл ['[he] brought into']. In English enters was used only once.

The image of a house was not identified in the English data. However, English is distinct in the ample use of opening and closing in reference to the beginning and end of poems. Thus, we come across such words and expressions as the poem opens, opening lines, opening sections, opening [of the poem]; the poem closes, closed the poem and near the close of the poem. These are rather conventional ways of expression in English. In Russian, opening seems to be possible but closing is not. Here, we come across such expressions as: поэзия оказалась открытой ['poetry turned out to be open'] and открывает вход [в стихотворении] ['opens the entrance into the poem']; no closing has been identified in the data.

The source domain of BUILDING has not been very numerously represented: only 12/12 cases were identified in English and 47/58 in Russian. The elements of the source domain of BUILDING in the data mostly refer to the process of building or construction in general or the foundational part of a building. This is in conformity with the findings of other authors, who claim that neither windows nor doors nor balconies are transferred to the target domain (see also Grady \& Johnson, 2000). In our data, we came across such expressions as the poem's structural scaffolding, the structure of Heaney's poetry, poetry built from, the poems are based on and Bidar constructs his counter-tradition in English, and Пушкин строил сюжет ['Pushkin built the story/plot'], выстраивать контекст ['to build/construct the context'], построение стихотворения ['the building of a poem'], конструировать иносказания ['to construct allegories'], эвфоническая структура [the euphonic structure'] and стихи основаны на ['the verse is based on'] in Russian. Russian seems to be much more prone to employing the element of construction. Therefore, in the corpus, we have such expressions as метафорическая конструкиия ['metaphoric construction'], 
риторические конструкиии ['rhetorical constructions'], словесная конструкиия ['verbal construction'], строфы образуют конструкиию ['stanzas form a construction'], among others.

Building experience, involving a great deal of hard manual labour, seems to evoke rather strong associations with writing poetry, which also requires much effort on the part of the author. Russian exploits the source domain of BUILDING more frequently than does English, particularly in reference to construction as a complex and intricate piece of work.

The source domain of A PLANT AND BIOLOGICAL PROCESS features very marginally, especially in English (3/4). It is signalled by such elements of the text as root and maturing. Rooting is associated with firmly established ideas, their relationship with values and traditions maintained in poetry. The process of maturation normally has to do with development. In the two cases in English, the maturation refers to the professional development of a poet, one of them is given below:

\section{(34) But in his short life Keats matured into a poet engaged in thoughtful} discussion of more serious concerns [...] (EN24).

In Russian, the source domain of A PLANT AND BIOLOGICAL PROCESS is employed more frequently (34/39) and refers to almost all stages of biological development. The element of root only appears once; however, sprouts, growing, maturing, branches, buds, and especially blossoms and blossoming, are frequent. In our corpus, we can see cases like поэзия в наши дни переживает расивет ('poetry lives the days of blossoming'), легенда составляет особую ветвь ('the legend makes up a special branch'), стихи вырастают ('the verse is growing'), смыслы прорастают ('the meanings grow through'), and the like. The expression of blossoming poetry is a fairly well-established ME and, according to Deignan (2005, p. 39-47), could be considered a 'conventionalized linguistic metaphor'. It seems to be that which is frequently used to express praise and appreciation by literary critics.

By contrast, growing, from the evaluative point of view, is far from unambiguous. What grows naturally seems to be good and healthy; however, if a plant fails to reach some standard height, it is considered unhealthy. In the expression дорасти до поэзии ['to grow up to poetry'], poetry is considered to be the standard. Thus, if a person's attempts to write are not sufficiently valuable, they fail to grow up to poetry, as illustrated in the following example: 
(35) [...] записнье книжки находятся лишь на первом уровне отбора материала, который может претендовать на то, чтобы когдалибо дорасти до поэзии ['drafts are just the first stage of material selection which can make claims to grow up to poetry someday'] (RU10).

Interestingly enough, the stage of biological development, when blossoms fall and plants begin to die, rarely appears in our corpus. The only case that indicates a lack of vitality, and thus expresses the critic's negative attitude towards almost forgotten poetry, is his mention of the genre of poetry as overgrown with burdock ([жанр поэзии] зарос лопухом).

Thus literary criticism focusing on poetry in Russian seems to employ the source domain of A PLANT AND BIOLOGICAL PROCESS more consistently. Conceptual correspondences have been identified at different phases of the plant's growth. English only occasionally employs this source domain.

The source domain of FOOD has been employed in a single case in English and several cases in Russian (6/7). The MEs produced in both languages are interesting and innovative. English refers to seasoning the lines in local dialect, expressing the idea that dialectal forms add to the expressiveness of poetry. Russian employs the elements of juiciness, freshness and tastiness, all of which signal the author's appreciation of poetry. Juiciness has been employed in three out of seven cases. Thus, not only lines or details can be juicy (сочные строчки and сочные детали, respectively), but also images, for example: сочный образеи русского стиха ['juicy image of the Russian verse']. Lines can also be tasty («вкусные» строчки) or easily swallowed (стихи проглоченные), which means that they are masterfully written and can thus be easily read (=swallowed). Such cases are manifestations of the well-known metaphor IDEAS ARE FOOD (see also Lakoff \& Johnson, 2003; Kövecses, 2002).

The source domain of DISEASE has been identified in only a few cases in Russian (7/8); no English examples with this source domain were identified. The elements of disease employed in the MEs are related to immunity and infecting someone, causing a disease. However, it is interesting to note that having no immunity or having low immunity to poetry is seen as a positive feature. In other words, such people are open to poetry and are therefore appreciated by critics, for example: 
(36) [...] любители стихов - это люди с пониженным иммунитетом [...]. ['Poem-lovers are people with a weaker [lowered] immunity'] (RU25).

If a poet is unable to infect readers with his/her poetry, the aim of the poet will not be attained and the poetry will not be read. By pointing out this feature of poetry, critics indirectly express their negative evaluation, for example:

(37) Чухониев [...] не «заражсает» читателя собой. ['Tchukhoncev does not infect the reader with himself'] (RU10).

In such cases, an analogy is most likely drawn between the image of a disease penetrating a human organism and the ideas entering the human mind in the process of reading. Even though the images clash, as diseases evoke negative associations and ideas, and reading is positive, such a clash surprises the reader and he/she manages to interpret the collocation. The critic thus manifests metaphorical creativity not so much by coming up with a novel metaphor, but rather by disclosing some innovative aspects of already existing metaphors.

\section{Conclusion}

The present investigation has demonstrated that the discourse of literary criticism focusing on poetry is mainly structured through the source domain of A PERSON (LIVING ORGANISM). Its different aspects seem particularly important for English, where this metaphor in its linguistic manifestation exceeds Russian by nearly threefold. Poems and other texts tend to acquire the ability to speak; they are characterized by some physical features of a human being, as well as certain character features and emotions. In Russian, emotionrelated words and expressions, as well as those referring to character features, are more numerous and diverse than in English. English, on the other hand, has numerous cases where poems or lines speak, mention or explain.

Other metaphors identified in both discourses draw largely on the source domains of SOUND AND MUSIC, PAINTING, JOURNEY and CONTAINER. The source domains of JOURNEY and CONTAINER are also frequent in many other types of discourses. Some more peripheral source domains, such as BUILDING, HANDICRAFTS (WEAVING AND SEWING), FILMING, PLANTS, FOOD and 
DISEASE feature less prominently in our data. The domain of DISEASE has only been identified in Russian.

Two rather distinct source domains of SOUND AND MUSIC and PAINTING have turned out to be very important for Russian literary criticism about poetry. SOUND AND MUSIC might suggest that Russian critics give more attention to acoustic properties of poetry; PAINTING would imply that verbal information is easily visualized.

Therefore, the frequently employed source domain of SOUND AND MUSIC in Russian data suggests that the persistent claim of cognitivists about a correlation between more concrete and more abstract domains must be revised, since the source domain of MUSIC is no less concrete than reasoning about poetry. The revision should take into consideration such rather specific discourses as literary criticism.

Although the findings are, in principle, not very surprising, the fact that English employs the source domain of A PERSON so frequently might be indicative of human-centred reasoning in the English-speaking culture. This is a rather tentative claim, which calls for further research to be fully confirmed.

Despite some culture-specific realizations of many metaphors in literary criticism, it is still obvious that a large part of metaphors are crosscultural, if not universal. This could be explained, as claimed by Kövecses (2006, p. 156-157), by three main reasons. He admits that first, it happens by mere chance; second, languages borrow metaphors from each other; and, finally, there exists some universal motivation that encourages the emergence of commonly used metaphors. That universal motivation seems to be common human experience, often termed as embodiment (JOHNSON, 2007).

As to the third question raised at the beginning of the paper, literary criticism is evaluative and metaphors in many cases help render the evaluation. Thus, describing poetry as blossoming seems to be a clear expression of appreciation; if someone's attempts to write are described as rather immature, they are probably not worthy of praise. This paper, however, did not focus exclusively on evaluation, nor did it attempt to attribute the identified linguistic metaphors (or MEs) to dead, entrenched, conventionalized and innovative metaphors, as this seems to be a matter of degree than clear-cut division (see also Deignan, 2005). In terms of evaluative power, it seems that innovative metaphors are much more evaluative than 
conventionalized. However, further investigation is warranted to more completely prove or disprove this claim.

\section{Acknowledgements}

We are grateful to two anonymous reviewers of the paper for their insightful comments.

\section{References}

CIBULSKIENĖ, J. What is economic recession: a (pot)hole or a burden? A crosscultural study of the conceptualization of economic recession via the JOURNEY metaphor. In: ŠEŠKAUSKIENĖ, I.; GRIGALIŪNIENĖ, J. (Eds.). Anglistics in Lithuania: Cross-Linguistic and Cross-Cultural Aspects of Study. Newcastle upon Tyne: Cambridge Scholars Publishing, 2013. p. 64-93.

DEIGNAN, A. Metaphor and Corpus Linguistics. Amsterdam: John Benjamins, 2005. $235 \mathrm{p}$.

FLØTTUM, K. et al. Cultural identities and academic voices. In: FLØTTUM, K. (Ed.). Language and Discipline Perspectives on Academic Discourse. Newcastle upon Tyne: Cambridge Scholars Publishing, 2007. p. 14-40.

GIBBS, R. W. Jr.; LIMA, P. L. C.; FRANCOZO, E. Metaphor is grounded in embodied experience. Journal of Pragmatics, Amsterdam, v. 36, p. 1189-1210, 2004. GRADY, J.; JOHNSON, Ch. Converging evidence for the notions of subscene and primary scene. In: DIRVEN, R.; PÖRINGS, R. (Eds.). Metaphor and Metonymy in Comparison and Contrast. Berlin: Mouton de Gruyter, 2000, p. 533-554.

HERRMANN, J. B. Metaphor in Academic Discourse. Linguistic forms, conceptual structures, communicative functions and cognitive representations. 2013.361 p. Dissertation (Ph.D.) - Vrije Universitet, Amsterdam.

HEYWOOD, J.; SEMINO, E.; SHORT, M. Linguistic metaphor identification in two extracts from novels. Language and Literature, London, v.11, n. 1, p. 35-54. 2002. HYLAND, K. A convincing argument: corpus analysis and academic persuasion. In: CONNOR, U.; UPTON, T. A. (Eds.). Discourse in the Professions. Amsterdam: John Benjamins, 2004, p. 87-112.

JOHNSON, M. The Meaning of the Body. Chicago: University of Chicago Press, 2007.308 p.

JOHNSON, M.; LARSON, S. "Something in the way she moves": metaphors of musical motion. Metaphor and Symbol, London, v. 18, p. 63-84. 2003. 
KÖVESCES, Z. Metaphor: A Practical Introduction. Oxford: Oxford University Press, 2002. 285 p.

KÖVESCES, Z. Language, Mind, and Culture. Oxford: Oxford University Press, $2006.397 \mathrm{p}$.

KÖVESCES, Z. Metaphor: A Practical Introduction. $2^{\text {nd }}$ ed. Oxford: Oxford University Press, 2010. 375 p.

LAKOFF, G. Women, Fire, and Dangerous Things. Chicago: University of Chicago Press, 1987.614 p.

LAKOFF, G.; JOHNSON, M. Metaphors We Live By. $2^{\text {nd }}$ ed. Chicago: University of Chicago Press, 2003. 276 p.

LAKOFF, G.; JOHNSON, M. Philosophy in the Flesh. New York: Basic Books, $1987.624 \mathrm{p}$.

LOW, G. "The paper thinks...": Investigating the acceptability of the metaphor AN ESSAY IS A PERSON. In: CAMERON, L.; LOW, G. (Eds.) Researching and Applying Metaphor, Cambridge: Cambridge University Press, 1999. p. 221-248. NÚNEZ, R. Conceptual metaphor, human cognition, and the nature of mathematics. In: GIBBS, R.W. Jr. (Ed.). The Cambridge Handbook of Metaphor and Thought. Cambridge: Cambridge University Press, 2008. p. 339-362.

SOANES, C.; STEVENSON, A. (Eds.) Oxford Dictionary of English. $2^{\text {nd }} \mathrm{rev}$. ed. Oxford: Oxford University Press, 2005.

PRAGGLEJAZ GROUP. MIP: a method for identifying metaphorically used words in discourse. Metaphor and Symbol, London, v. 22, n. 1, p. 1-39. 2007.

SEMINO, E. A corpus-based study of metaphors for speech activity in British English. In: STEFANOWITSCH, A. and GRIES, S. Th. (Eds.). Corpus Approaches to Metaphor and Metonymy. Berlin: Mouton de Gruyter, 2006. p. 36-62.

SEMINO, E. Metaphor in Discourse. Cambridge: Cambridge University Press, 2008. SEMINO, E. The adaptation of metaphors across genres. Review of Cognitive Linguistics, Amsterdam, n. 9, v. 1, p. 130-152, 2011.

SEMINO, E.; STEEN, G. Metaphor in literature. In: GIBBS, R.W. Jr. (Ed.). The Cambridge Handbook of Metaphor and Thought. Cambridge: Cambridge University Press, 2008. p. 232-246.

ŠEŠKAUSKIENĖ, I. Who discusses: the paper or the author of the paper? Inanimate subject + active verb in Lithuanian linguistic discourse as compared to English. Respectus Philologicus, Kaunas, v. 18, n. 23, p. 83-99, 2010. 
ŠEŠKAUSKIENĖ, I. Metaphoricity of academic metadiscourse: what can be raised in English and Lithuanian? In: ŠEŠKAUSKIENĖ, I. and GRIGALIŪNIENĖ, J. (Eds.). Anglistics in Lithuania: Cross-Linguistic and Cross-Cultural Aspects of Study. Newcastle upon Tyne: Cambridge Scholars Publishing, 2013. p. 93-120.

STEEN, G.J. Can discourse properties of metaphor affect metaphor recognition? Journal of Pragmatics, Amsterdam, v. 36, p. 1295-1313, 2004.

STEEN, G.J. et al. Metaphor in usage. Cognitive Linguistics, Berlin, v. 21, n. 4, p. 765-796, 2010.

STEEN, G.J. et al. A Method for Linguistic Metaphor Identification. Amsterdam: John Benjamins, 2010a. 238 p.

STEFANOWITSCH, A. Happiness in English and German: a metaphorical pattern analysis. In: ACHARD, M.; KEMMER, S. (Eds.). Language, Culture, and Mind. Stanford: CSLI Publications, 2004. p. 137-149.

STEFANOWITSCH, A. Words and their metaphors. In: STEFANOWITSCH, A.; GRIES, S.Th. (Eds.). Corpus-Based Approaches to Metaphor and Metonymy. Berlin: Mouton de Gruyter, 2006. p. 63-105.

ZINKEN, J.; HELLSTEN, I.; NERLICH, B. Discourse metaphors. In: FRANK, R. M. et al. (Eds.). Body, Language and Mind, v. 2: Sociocultural Situatedness. Berlin: Mouton de Gruyter, 2008. p. 363-386.

\section{Sources}

EN1 - AXELROD, S. G. Frank Bidart's "Inauguration Day". The American Poetry Review, Philadelphia, v. 40, n. 2, p. 39-41, 2011.

EN2 - BLEVINS, A. Critical Essay on "For Jennifer, 6, on the Teton". In: GALENS, D. A. (Ed.). Poetry for Students. Detroit: Gale, 2003. p. 27-29.

EN3 - BORUCH, M. From "Poets in Cars". The American Poetry Review, Philadelphia, v. 39, n. 4, p. 34, 2010.

EN4 - BROGAN, J.V. Poems against His Climate. In: LEE, M. (Ed.). Poetry Criticism. Detroit: Gale, 2003, p. 9-13.

EN5 - BUCKLEY, Ch. An Outtakes Sestet: "Sky Guy”. Northwest Review, Eugene, v. 49, n. 2, p. 110-111, 2011.

EN6 - BURT, S. “The Dark Garage with the Garbage”: Louise Glück's. In: HUNTER, J.W. (Ed.). Contemporary Literary Criticism. Detroit: Gale, 2005. p. 74-89.

EN7 - CARLSON, M. P. A secret kept: interpreting Rossetti’s “The Stream's Secret". The Explicator, London, v. 67, n. 2, p. 135-139, 2009. 
EN8 - COMET, N. Letitia Landon and Romantic Hellenism. Wordsworth Circle, Boston, v. 37, n. 2, p. 76-80, 2006.

EN9 - CORDING, R. The Otherworldliness of Elizabeth Bishop. The Worcester Review, Worcester, v. 32, n. 1-2, p. 41-46, 2011.

EN10 - DILWORTH, T. Parallel light shows in Coleridge's "The Rime of the Ancient Mariner". The Explicator, London, v. 65, n. 4, p. 212-215, 2007.

EN11 - DOTY, M. A Tremendous Fish. New England Review, Los Angeles, v. 31, n. 2, p. 58-66, 2010.

EN12 - HALL, J. D. Rhyme in "Seamus Heaney's Group Poems”. In: LEE, M. (Ed.). Poetry Criticism. Detroit: Gale, 2004. p. 55-60.

EN13 - HAMMOND, B. S. "The Dunciad" and the City: Pope and Heterotopia. Studies in the Literary Imagination, Atlanta, v. 38, n. 1, p. 219-232, 2005.

EN14 - HILL, P. S. Critical Essay on "The Blue Rim of Memory". In: GALENS, D.A. (ed.). Poetry for Students. Detroit: Gale, 2003. p. 40-43.

EN15 - IANNONE, C. John Greenleaf Whittier's "Civil War". Modern Age, Chicago, v. 42, n. 2, p. 132-138, 2005.

EN16 - KELLY, D. Critical Essay on "Proem". In: GALENS, D.A. (Ed.). Poetry for Students, Detroit: Gale, 2004. p. 57-61.

EN17 - KOEZLER, R. Abrams among the Nightingales: revisiting the greater Romantic lyric. Wordsworth Circle, Boston, v. 37, n. 2, p. 67-71, 2006.

EN18 - MCCULLOCH, A. "An Arundel Tomb" by Philip Larkin: Andrew McCulloch looks at the relationship between form and meaning in one of Larkin's most popular poems. The English Review, London, v. 15, n. 2, p. 30, 2004.

EN19 - MCINNIS, D. Humoral theory as an organizing principle in Shelley's "Ode to the West Wind"? ANQ, Kentucky, v. 20, n. 2, p. 32-34, 2007.

EN20 - MILLER, J. Auden's September 1, 1939. The Explicator, London, v. 62, n. 2, p. 115-118, 2004.

EN21 - O'GRADY, T. B. "I have seen it": Elizabeth Bishop as Maritime Poet". The Worcester Review, Worcester, v. 32, n. 1-2, p. 33-39, 2011.

EN22 - PALMER, J. Stevens's "The Poems of Our Climate". The Explicator, London, v. 61, n. 4, p. 220, 2003.

EN23 - ROBBINS, J. "At the Fishhouses" and "The Moose": A Comparison. The Worcester Review, Worcester, v. 32, n. 1-2, p. 47-51, 2011.

EN24 - SWALE, J. John Keats: romantic or realist? Jill Swale considers Keats's exploration of the relationships between poetry, imagination and the realities of human existence. The English Review, London, v. 15, n. 1, p. 24, 2004. 
EN25 - THOMPSON, Ch. A Science of Subjectivity. The American Poetry Review, Philadelphia, v. 38, n. 6, p. 31-33, 2009.

EN26 - WHITE, D. The Game Plan of "The Hunting of the Snark". In: LEE, M. (Ed.). Poetry Criticism, Detroit: Gale, 2006. p. 63-66.

EN27 - WRIGHT, J. A reflection on fiction and art in "The Lady of Shalott". Victorian Poetry, Morgantown, v. 41, n. 2, p. 287, 2003.

RU1 - АБДУЛАЕВ, Е. Книжная полка Евгения Абдулаева. Новый мир, Moscow, v. 4, p. 225-230, 2011. Available at: http://magazines.russ.ru:81/novyi_ mi/2011/4/kn12.html. Accessed 12 September 2012.

RU2 - БАК, Д. Сто поэтов начала столетия. Октябрь, Moscow, v. 7, p. 172179, 2011. Available at: http://magazines.russ.ru/october/2011/1/ba22.html. Accessed 25 September 2012.

RU3 - БЕНЕВИЧ, Г. Два этюда о творчестве Евгения Кропивницкого. Новое литературное обозрение, Моscow, v. 113, n. 1, p. 236-248, 2012. Available at: http://www.nlobooks.ru/node/1763. Accessed 14 October 2012.

RU4 - ВЕЖЛЯН, Е. Стратегия тотального синтеза. Новый мир, Moscow, v. 4, p. 216-222, 2011. Available at: http://magazines.russ.ru/novyi_mi/2011/4/ ve10.html. Accessed 25 October 2012.

RU5 - ГОРЕЛИК, М. Флейта. Новый мир, Moscow, v. 2, p. 181-186, 2009. Available at: http://magazines.russ.ru/novyi_mi/2009/2/go19.html. Accessed 11 July 2012

RU6 - ГРОДСКАЯ, Е. «Сам себе стих». Новый мир, Moscow, v. 3, p. 161166, 2010. Available at: http://magazines.russ.ru/novyi_mi/2010/3/gr11.html. Accessed 15 July 2012.

RU7 - ГУБАЙЛОВСКИЙ, В. Перебирая времена. Новый мир, Moscow, v. 1, p. 169-173, 2009. Available at: http://magazines.russ.ru/novyi_mi/2009/1/gu18. html. Accessed 15 June 2012.

RU8 - ЖИТЕНЕВ, А. Михаил Еремин: поэтика словаря. Новое литературное обозрение, Moscow, v. 113, n. 1, p. 225-235, 2012. Available at: http://www.nlobooks.ru/node/1762. Accessed 14 October 2012.

RU9 - ЗОЛОТЦЕВ, С. Честь, сбережённая смолоду. Наш современник, Moscow, v. 11, p. 265-270, 2008.

RU10 - КОЗЛОВ, В. Внутренние пейзажи Олега Чухонцева. Новый мир, Moscow, v. 3, p. 158-173, 2008. Available at: http://magazines.russ.ru/novyi_ $\mathrm{mi} / 2008 / 3 / \mathrm{ko} 13 . \mathrm{html}$. Accessed 30 July 2012. 
RU11 - КОНОНОВ, В. «Веленью Божию, о муза, будь послушна...». Haш современник, Moscow, v. 6, p. 260-265, 2010.

RU12 - КОСТЮКОВ, Л. Время собирать камни. Новый мир, Moscow, v. 5 , p. 172-175, 2009. Available at: http://www.safmuseum.org/press/472/. Accessed 28 June 2012.

RU13 - КОСТЮКОВ, Л. Интонации нового века. Новый мир, Moscow, v. 4, p. 177-185, 2010. Available at: http://magazines.russ.ru/novyi_mi/2010/4/ko11. html. Accessed 12 September 2012.

RU14 - КУЗЬМИЧ, М. Властная сила жизни. Наш современник, Moscow, v. 12, p. 270-275, 2008.

RU15 - ЛОШИЦ, Ю. Поэт и богема. Наш современник, Moscow, v. 5, p. 277-280, 2011.

RU16 - МАКСИМОВИЧ, В. Путь согласия, гармонии и правды. Наш современник, Moscow, v. 12, p. 261-266, 2007.

RU17 - НЕВЗГЛЯДОВА, Е. «Прислушайся к мраку». Новый мир, Moscow, v. 3, p. 176-179, 2008. Available at: http://magazines.russ.ru/novyi_mi/2008/3/ ne15.html. Accessed 14 January 2013.

RU18 - НОВГОРОДСКИЙ, Ю. Трактовка природы в поэзии Дилана Томаса как признак возрождения романтической традиции. Филология в системе современного университетского образования, Moscow, v. 7, p. 190-194, 2004. Available at: http://www.philology.ru/literature3/novgorodsky-04.htm. Accessed 12 January 2013.

RU19 - РАНЧИН, А. От бабочки к мухе. Новый мир, Moscow, v. 5, p. $166-$ 180, 2010. Available at: http://magazines.russ.ru/novyi_mi/2010/5/ra12.html. Accessed 28 June 2012.

RU20 - РОДНЯНСКАЯ, И. Буквы и голос. Новый мир, Moscow, v. 5, p. $166-$ 172, 2009. Available at: http://magazines.russ.ru/novyi_mi/2009/5/ro13.html. Accessed 15 October 2012.

RU21 - СУРАТ, И. «И новый человек ты будешь...». Новый мир, Moscow, v. 5, p. 152-172, 2009. Available at: http://magazines.russ.ru/novyi_mi/2009/5/ su11.html Accessed 12 October 2012.

RU22 - УСПЕНСКИЙ, П. Механизмы русского футуризма: «тепло» Бенедикта Лившица. Bопросы литературы, Moscow, v. 3, p. 166-191, 2012. RU23 - ЧЕX, А. Орнаментальный принцип в поэзии Николая Клюева. Народная культура сегодня и проблемы её изучения, Voronezh, v. 7, p. 97-116, 2006. Available at: http://www.philology.ru/literature2/cheh-06.htm. Accessed 15 January 2013. 
RU24 - ШАЙТАНОВ, И. Одноразовая форма. Вопросы литературы, Moscow, v. 1, p. 239-251, 2011.

RU25 - ШТЫПЕЛЬ, А. Нами лирика. Новый мир, Moscow, v. 2, p. $172-$ 178, 2009. Available at: http://magazines.russ.ru/novyi_mi/2009/2/sch17.html. Accessed 12 September 2012.

RU26 - ЩЁЛОКОВ, И. «И дороги иные, и приметы не те...». Haw современник, Moscow, v. 6, p. 279-284, 2010.

Data de submissão: 20/02/2014. Data de aprovação: 25/07/2014. 